\title{
Yield and quality improvement in Bt cotton through foliar application of trifloxystrobin and tebuconazole
}

\section{G. Karuppusamy*}

Department of Crop Physiology, Agriculture College and Research Institute, Tamil Nadu Agricultural University, Coimbatore-641003 (Tamil Nadu), India

\section{N. Chandrasekhar}

Department of Crop Physiology, Agriculture College and Research Institute, Tamil Nadu Agricultural University, Coimbatore-641003 (Tamil Nadu), India

\section{P. Jeyakumar}

Department of Crop Physiology, Agriculture College and Research Institute, Tamil Nadu Agricultural University, Coimbatore-641003 (Tamil Nadu), India

\section{Gunasekaran}

National Pulses Research Centre, Vamban-622303 (Tamil Nadu), India

${ }^{*}$ Corresponding author. Email: karuppusamy627@gmail.com

\section{Article Info}

https://doi.org/10.31018/ jans.v13iSI.2806

Received: March 22, 2021

Revised: May 14, 2021

Accepted: June 3, 2021

\section{How to Cite}

Karuppusamy, G. et al. (2021). Yield and quality improvement in Bt cotton through foliar application of trifloxystrobin and tebuconazole. Journal of Applied and Natural Science, 13 (SI), 94 - 99. https://doi.org/10.31018/jans.v13iSI.2806

\begin{abstract}
In agriculture, fungi can cause serious damage, resulting in critical losses of yield, quality and profit. Fungicides help in reducing the damage caused by fungus, reduce the yield loss and play a major role in quality improvement. The present investigation was carried out at Tamil Nadu Agricultural University to evaluate the influence of trifloxystrobin $50 \%+$ tebuconazole $25 \%$ (Nativo 75WG) on the yield and quality improvement on Bunny hybrid Bt cotton. Nativo 75WG was applied on the leaves of cotton plants at 40-60 (DAS) and 60-80 (DAS) at the concentration of 250, 300, $350 \mathrm{~g} / \mathrm{ha}$ and Carbendazim @ $500 \mathrm{~g} / \mathrm{ha}$. The observations recorded were related to yield and quality attributes in all treatments. The application of Nativo @ $300 \mathrm{~g} / \mathrm{ha}$ showed a significant increase in boll weight $(4.86 \mathrm{~g})$, lint yield per boll $\left(3.86 \mathrm{~g} \mathrm{boll}^{-1}\right)$ and lint per plant $\left(138.48 \mathrm{~g}\right.$ plant $\left.{ }^{-1}\right)$ than other treatments. With respect to seed cotton yield and harvest index $(0.37 \%)$, the Nativo @ $300 \mathrm{~g} / \mathrm{ha}$ registered a higher yield $(20.2 \%)$ and $\mathrm{HI}$ than control under the irrigated situation. Foliar application of treatments during the flowering stage (40-60 DAS) and boll formation stages (60-80 DAS) had increased the quality parameters such as fiber length $(2.5 \%$ staple length, 50 $\%$ staple length) and fiber strength. Further, the foliar spray of Nativo @ $300 \mathrm{~g} / \mathrm{ha}$ applied to bunny hybrid Bt cotton had resulted in a higher yield $\left(2920.15 \mathrm{~kg} \mathrm{ha}^{-1}\right)$ due to an increase in leaf area index, greenness of leaf and higher dry matter production of the plant.
\end{abstract}

Keywords: Boll, Fiber, Leaf area index, Tebuconazole, Trifloxystrobin

\section{INTRODUCTION}

Cotton is a white fibrous agricultural product that has a wide variety of uses from textile production to creating paper, producing oil and food products. It is the most important global cash crop and controls the economy of many nations. Fungicides remain a vital solution to the effective control of plant diseases, which are estimated to cause yield reductions of almost 20 per cent in major food and cash crops worldwide. Today, fungal pathogens can be effectively controlled by broad-spectrum fungicides such as the strobilurin group which also serves as growth regulator for improvising the yield.
They have a suppressive effect on other fungi, reducing competition for nutrients; they inhibit electron transfer in mitochondria, disrupting metabolism and preventing growth of the fungi (Ammermann et al., 2000).

Trifloxystrobin belongs to the strobilurin group of fungicide which is a mesostemic and broad-spectrum fungicide with preventive and specific curative activity. It displays rain-fastness property, translocates by superficial vapour movement and also has translaminar activity. Similarly, Tebuconazole is a systemic triazole fungicide that is used widely in agricultural practices to manage phyto-pathogenic fungi such as Curvularia spp., Fusarium spp., etc. It is reported to kill the target organ- 
isms by disrupting the membrane functions through sterol biosynthesis inhibition (Debashis et al., 2012) Nativo 75 WG is a water dispersible granular formulation containing 25 per cent w/w trifloxystrobin and 50 per cent w/w tebuconazole by M/S Bayer Crop- Science (Patil et al., 2018; Bag et al., 2016; Sahoo et al., 2011).

From intense research made in the last decade on the fungicidal properties of strobilurins and triazoles on the metabolism of pathogenic fungi, positive influences on host physiology and consequently on yield formation have been recognized in plants (Beck et al., 2000). The objective of this research was to evaluate the effect of trifloxystrobin + tebuconazole fungicides on the yield and quality of Bt cotton.

\section{MATERIALS AND METHODS}

A field experiment was conducted to study the effect of trifloxystrobin + tebuconazole on Bunny hybrid Bt cotton. Spraying with Nativo 75WG at different concentration along with Carbendazim $\left(\mathrm{T}_{1^{-}}\right.$control, $\mathrm{T}_{2^{-}}$trifloxystrobin + tebuconazole @ $250 \mathrm{~g} / \mathrm{ha}, \mathrm{T}_{3^{-}}$trifloxystrobin + tebuconazole @ 300 g/ha, T4- trifloxystrobin + tebuconazole @ 350 g/ha, $T_{5^{-}}$carbendazim @ $500 \mathrm{~g} / \mathrm{ha}$ ) was carried out in 40 DAS, 60 DAS, 80 DAS and 120 DAS. The leaf area was measured with Leaf Area Meter (Model LI 3100, Li-Cor, Inc. Nebraska, and U.S.A.) and expressed in $\mathrm{cm}^{2}$ per plant, and Leaf area index (LAI) was calculated using the following formula as suggested by Ashley et al. (1965) and using the crop DMP recorded during the respective stages, as suggested by Watson. (1958).

The weight of ten fully opened bolls collected from the plot was recorded and expressed as mean boll weight in $\mathrm{g} \mathrm{boll}^{-1}$. Circumference of boll was measured by using thread in center diameter of boll the boll girth was measured and expressed in $\mathrm{cm}$. The weight of lint from the yield of first picking for each replication of all treatments was estimated and the mean value was determined and expressed as $\mathrm{g} \mathrm{boll}^{-1}$ and lint yield per plant $\left(\mathrm{g}\right.$ plant $\left.^{-1}\right)$. The seed cotton yield was recorded and the mean values expressed in $\mathrm{kg} \mathrm{ha}^{-1}$. Harvest index was calculated by using Economic yield and Biological yield (Yoshida, 1971). Fiber characters were determined by "High Volume Instrument" using the standard test methods (Sundaram, 1979).

\section{RESULTS AND DISCUSSION}

\section{Total dry matter production (g plant ${ }^{-1}$ )}

Among the different treatments, plants with Nativo @ $300 \mathrm{~g} / \mathrm{ha}\left(\mathrm{T}_{3}\right)$ on 120 DAS (Table 1) recorded highest TDMP recording 13.5 per cent over control, which relatively explained the effect or efficiency of the Nativo treatment. Higher TDMP was recorded in Nativo treated plants than the control plants by the application of strobilurin combined with triazole as reported earlier by Lima et al. (2012) in banana, Ruske et al. (2003) in wheat and Rezende et al., 2018 in maize. The exogenous application of triazole compounds significantly altered the total biomass accumulation and partitioning patterns in sesame (Mehmood et al., 2021). Enhanced nutrient and water translocation within the plants under triazole compounds application increase the biomass production of plants (Kamran et al. 2018; Kuai et al. 2015). Translocation of assimilates to the growing reproductive parts is the major constraint in crop production, which can overcome by the physiological effects of fungicide. In the present investigation, the TDMP in $\mathrm{Bt}$ cotton showed a significant increase at 60 DAS, 80 DAS and 120 DAS.

\section{Leaf area $\left(\mathrm{cm}^{2}\right.$ plant $\left.^{-1}\right)$}

The steady increase in leaf area was observed at all growth stages. After the fungicide application, the leaf area was significantly increased at 80 and 120 DAS (Table 2). Impact of fungicide concentrations on leaf area showed an increase of 40.6 per cent at 120 DAS with Nativo @ $300 \mathrm{~g} / \mathrm{ha}$. Similar results induced by triazoles could be the reason for reduced leaf expansion (Gopi et al., 2005). In winter wheat plants, addition of strobilurins to epoxiconazole increase green leaf area (GLA)

Table 1. Effect of Nativo (trifloxystrobin + tebuconazole) on total dry matter production (g plant ${ }^{-1}$ ) in Bunny hybrid Bt cotton (Average value of 5 observations from 4 replications of treatments).

\begin{tabular}{lllll}
\hline Treatment & 40 DAS & 60 DAS & 80 DAS & 120 DAS \\
\hline $\mathrm{T}_{1}$-Untreated control & 64.19 & 120.42 & 189.84 & 368.21 \\
$\mathrm{~T}_{2}$-Nativo @ 250 g/ha & 64.21 & 124.75 & 197.56 & 378.20 \\
$\mathrm{~T}_{3}$-Nativo @ 300 g/ha & 64.33 & 125.33 & 214.74 & 418.09 \\
$\mathrm{~T}_{4}$-Nativo @ 350 g/ha & 64.44 & 124.20 & 204.60 & 385.76 \\
T5-Carbendazim @ 500 g/ha & 63.88 & 123.24 & 194.67 & 376.60 \\
Mean & 64.21 & 123.59 & 200.28 & 385.37 \\
$\mathrm{SE}(\mathrm{d})$ & 0.59 & 1.14 & 1.89 & 3.66 \\
$\mathrm{CD}(\mathrm{P}=0.05)$ & $\mathrm{NS}$ & 2.48 & 4.12 & 7.98 \\
\hline
\end{tabular}


Karuppusamy, G. et al. / J. Appl. \& Nat. Sci. 13 (SI), 94 - 99 (2021)

Table 2. Effect of Nativo (trifloxystrobin + tebuconazole) on leaf area $\left(\mathrm{cm}^{2}\right.$ plant $\left.{ }^{-1}\right)$ in Bunny hybrid Bt cotton (Average value of 5 observations from 4 replications of treatments).

\begin{tabular}{lllll}
\hline Treatment & 40 DAS & 60 DAS & 80 DAS & 120 DAS \\
\hline $\mathrm{T}_{1}$-Untreated control & 6084.22 & 7245.70 & 8183.54 & 8618.46 \\
$\mathrm{~T}_{2}$-Nativo @ $250 \mathrm{~g} / \mathrm{ha}$ & 6027.43 & 7347.00 & 9146.62 & 10458.22 \\
$\mathrm{~T}_{3}$-Nativo @ 300 g/ha & 6088.94 & 7540.20 & 10797.90 & 12122.91 \\
$\mathrm{~T}_{4}$-Nativo @ 350 g/ha & 6004.24 & 7426.70 & 9283.21 & 11707.12 \\
T5-Carbendazim @ 500 g/ha & 6048.83 & 7368.20 & 8562.74 & 9587.70 \\
Mean & 6050.73 & 7385.56 & 9194.78 & 10498.88 \\
$\mathrm{SE}(\mathrm{d})$ & 55.58 & 68.29 & 90.88 & 102.67 \\
$\mathrm{CD}(\mathrm{P}=0.05)$ & $\mathrm{NS}$ & 148.79 & 198.01 & 223.71 \\
\hline
\end{tabular}

Table 3. Effect of Nativo (trifloxystrobin + tebuconazole) on Leaf area index (LAI) in Bunny hybrid Bt cotton (Average value of 5 observations from 4 replications of treatments).

\begin{tabular}{lllll}
\hline Treatment & 40 DAS & 60 DAS & 80 DAS & 120 DAS \\
\hline$T_{1}$-Untreated control & 1.13 & 1.34 & 1.52 & 1.60 \\
$\mathrm{~T}_{2}$-Nativo @ 250 g/ha & 1.12 & 1.36 & 1.69 & 1.94 \\
$\mathrm{~T}_{3}$-Nativo @ 300 g/ha & 1.13 & 1.40 & 2.00 & 2.24 \\
$\mathrm{~T}_{4}$-Nativo @ 350 g/ha & 1.11 & 1.38 & 1.72 & 2.17 \\
T5-Carbendazim @ 500 g/ha & 1.12 & 1.36 & 1.59 & 1.78 \\
Mean & 1.12 & 1.37 & 1.70 & 1.95 \\
$\mathrm{SE}(\mathrm{d})$ & 0.01 & 0.01 & 0.02 & 0.02 \\
$\mathrm{CD}(\mathrm{P}=0.05)$ & $\mathrm{NS}$ & 0.03 & 0.03 & 0.04 \\
\hline
\end{tabular}

Table 4. Effect of Nativo (trifloxystrobin + tebuconazole) on Boll weight per boll $(\mathrm{g})$, boll girth per boll $(\mathrm{cm})$, lint yield per boll ( $\mathrm{g}$ boll ${ }^{-1}$ ), lint yield per plant (g plant ${ }^{-1}$ ) in Bunny Hybrid Bt cotton (Average value of 5 observations from 4 replications of treatments).

\begin{tabular}{|c|c|c|c|c|}
\hline Treatment & $\begin{array}{l}\text { Boll weight } \\
\text { (g) }\end{array}$ & $\begin{array}{l}\text { Boll girth } \\
\text { (cm) }\end{array}$ & $\begin{array}{l}\text { lint yield boll } \\
\left(\mathrm{g} \text { boll }^{-1}\right)\end{array}$ & $\begin{array}{l}\text { lint yield plant } \\
\left(\mathrm{g}^{-1} \text { plant }^{-1}\right)\end{array}$ \\
\hline $\mathrm{T}_{1}$-Untreated control & 4.42 & 11.80 & 3.18 & 112.40 \\
\hline $\mathrm{T}_{2}$-Nativo @ $250 \mathrm{~g} / \mathrm{ha}$ & 4.64 & 12.40 & 3.48 & 126.12 \\
\hline $\mathrm{T}_{3}$-Nativo @ $300 \mathrm{~g} / \mathrm{ha}$ & 5.18 & 12.78 & 3.86 & 138.48 \\
\hline $\mathrm{T}_{4}$-Nativo @ $350 \mathrm{~g} / \mathrm{ha}$ & 4.86 & 12.52 & 3.67 & 132.42 \\
\hline T5-Carbendazim @ 500 g/ha & 4.78 & 12.32 & 3.37 & 124.50 \\
\hline Mean & 4.78 & 12.36 & 3.51 & 126.78 \\
\hline $\mathrm{SE}(\mathrm{d})$ & 0.05 & 0.12 & 0.03 & 1.21 \\
\hline$C D(P=0.05)$ & $0.10 \mathrm{BG}$ & 0.25 & 0.07 & 2.64 \\
\hline
\end{tabular}

or increase yield compared with epoxiconazole alone (McCartney et al., 2007 and Dietz et al., 2019 in oats). Leaf area and shoot, root and total plant dry masses were higher in triazole treated chestnut (Aesculus hippocastanum) trees than in control chestnut (Aesculus hippocastanum) trees. Finally triazole treated trees than by untreated trees, resulting in increasing total leaf area (Glynn and Kelly , 2008). Simarly, Triazole compounds treated plants have darker green foliage and more chlorophyll content in plants (Jiang et al., 2019; Tesfahun 2018). The results of the present study indicated that the influ- ence of Nativo on leaf area improvement.

\section{Leaf area index (LAl)}

In Nativo @ $300 \mathrm{~g} / \mathrm{ha}\left(\mathrm{T}_{3}\right)$ at 120 DAS, leaf are index increased significantly (Table 3 ) by the combination of trifloxystrobin and tebuconazole, with a record of 40 per cent against untreated control. The increase LAI observed in the present study might be due to significant increasing in leaf area in response to combination of strobilurin and triazole fungicide (Soumya et al., 2017; Pal et al., 2016). Similar to our results, a signifi- 
Table 5. Effect of Nativo (trifloxystrobin + tebuconazole) on seed cotton yield $\left(\mathrm{kg} \mathrm{ha}^{-1}\right)$ and harvest index in Bunny hybrid Bt cotton (Average value of 5 observations from 4 replications of treatments).

\begin{tabular}{lll}
\hline Treatment & Seed cotton yield $\left(\mathbf{k g ~ h a}^{-1}\right)$ & Harvest index \\
\hline $\mathrm{T}_{1}$-Untreated control & 2430.42 & 0.34 \\
$\mathrm{~T}_{2}$-Nativo @ 250 g/ha & 2640.32 & 0.35 \\
$\mathrm{~T}_{3}$-Nativo @ 300 g/ha & 2920.15 & 0.37 \\
$\mathrm{~T}_{4}$-Nativo @ 350 g/ha & 2830.44 & 0.37 \\
T5-Carbendazim @ 500 g/ha & 2550.20 & 0.34 \\
Mean & 2674.31 & 0.35 \\
$\mathrm{SE}(\mathrm{d})$ & 25.45 & 0.00 \\
$\mathrm{CD}(\mathrm{P}=0.05)$ & 55.44 & 0.01 \\
\hline
\end{tabular}

Table 6. Effect of Nativo (trifloxystrobin + tebuconazole) on $2.5 \%$ staple length, $50 \%$ staple length and fibre strength (g tex ${ }^{-1}$ ) in Bunny hybrid Bt cotton (Average value of 5 observations from 4 replications of treatments).

\begin{tabular}{llll}
\hline Treatment & $\mathbf{2 . 5 \%}$ staple length $\mathbf{( m m})$ & $\mathbf{5 0 \%}$ staple length $\mathbf{( m m})$ & Fibre strength $\mathbf{( g ~ t e \mathbf { ~ } ^ { - 1 } )}$ \\
\hline $\mathrm{T}_{1}$-Untreated control & 32.82 & 14.90 & 20.33 \\
$\mathrm{~T}_{2}$-Nativo @ 250 g/ha & 34.12 & 15.20 & 20.65 \\
$\mathrm{~T}_{3}$-Nativo @ 300 g/ha & 34.42 & 16.00 & 21.12 \\
$\mathrm{~T}_{4}$-Nativo @ 350 g/ha & 34.33 & 15.86 & 21.00 \\
T5-Carbendazim @ 500 g/ha & 34.00 & 15.00 & 20.67 \\
Mean & 33.94 & 15.39 & 20.75 \\
$\mathrm{SE}(\mathrm{d})$ & 0.31 & 0.14 & 0.19 \\
$\mathrm{CD}(\mathrm{P}=0.05)$ & 0.68 & 0.31 & 0.42 \\
\hline
\end{tabular}

cant increase in LAl was observed by Fleitas et al., 2018 in wheat, Muhammad and Honermeier (2012) in rape seed and soybean (Swoboda and Pedersen, 2009) by the application of fungicide (triazole and strobilurin).

\section{Yield and quality attributes}

In the present study, Nativo @ $300 \mathrm{~g} / \mathrm{ha}\left(\mathrm{T}_{3}\right)$ ranked first among all the treatments under irrigated condition, which showed maximum increased in yield components (Table 4), and Nativo @ $300 \mathrm{~g} / \mathrm{ha}\left(\mathrm{T}_{3}\right)$ recorded the highest seed cotton yield over the control with an increase of 20.2 per cent (Table 5). Harvest index also indicated that the efficiency of the plant to divert photosynthates to economic parts in biomass production. This present investigation was supported by the finding of fungicide application particularly strobilurins improved grain yield through improvements in both crop biomass and harvest index and the relationship with higher green leaf area duration of the flag leaf (Ruske et al., 2003). The addition of triazole with strobilurin increased the green leaf area index and seed yield in mustard (Muhammad and Honermeier 2012), Souza et al., 2020 in cotton; Bingham et al ., 2021 in barley and Mehmood et al., 2021 in sesame. A significant improvement in yield and yield components were noticed in Nativo @ 300 g/ha treated Bt cotton. The increased translocation of assimilates from the source to the developing sink is an indication for increased yield.

The quality characters such as $2.5 \%$ staple length, 50 $\%$ staple length and fiber strength were examined for the combined effect of trifloxystrobin and tebuconazole (Nativo) in Bt cotton. Among these five treatments, $\mathrm{Na}$ tivo @ $300 \mathrm{~g} / \mathrm{ha}\left(\mathrm{T}_{3}\right)$ recorded higher values than the control. The per cent increase due to fungicide application over control is 5 and 7.4 per cent for $2.5 \%$ Staple length and $50 \%$ staple length, respectively (Table 6). In the present investigation, the fiber strength out turn has registered higher value in fungicide application than in control. The Nativo @ 300 g/ha $\left(\mathrm{T}_{3}\right)$ had a higher value for fiber strength over the control increasing 4.0 per cent. Majumdar et al. (2010) reported that fungicides (trifluralin) recorded significantly higher fiber yield (74.7 $-78.9 \%$ ) over the control, while studying the effect of 
fungicides application on fiber yield in jute (corchorus olitorius). Similarly, the application of triazole compounds increased seed weight in canola and maize, while it has the tendency to reduce the seeds number per capsule at higher application concentrations (Kamran et al. 2018; Kuai et al. 2015). Muhammad and Honermeier (2012) reported that combined application of fungicides (triazole and strobilurin) with interaction of nitrogen appeared to delay the senescence, avoid lodging and improve quality components of winter rapeseed.

\section{Conclusion}

A significant improvement in yield and yield components was noticed in Nativo @ 300 g/ha treated Bt cotton. The increased translocation of assimilates from the source to the developing sink is an indication of increased yield. Quality attributes such as fiber length (2.5\% staple length and $50 \%$ staple length) and fiber strength were significantly $(P<0.05)$ enhanced by the combination of trifloxystrobin and tebuconazole. The present study demonstrated the preservative effect of trifloxystrobin $50 \%+$ tebuconazole $25 \%$ (Nativo 75WG) fungicide in improving $\mathrm{Bt}$ cotton yield and qualityn.

\section{Conflict of interest}

The authors declare that they have no conflict of interest.

\section{REFERENCES}

1. Ammermann E, Lorenz G, Schelberger $\mathrm{K}$, Mueller $\mathrm{B}$, Kirstgen R \& Sauter H (2000) BAS $500 \mathrm{~F}$ - the new broad-spectrum strobilurin fungicide. In: Proceedings of Brighton Crop Protection Conference, Pests and Diseases, Vol. 2 (pp. 541-548) British Crop Protection Council, Farnham, Surrey, UK. Ashley, D. A., Doss, B. D. \& Bennett, O. L. (1965). Relation of cotton leaf area index to plant growth and fruiting. Agronomy Journal, 57, 61-64.

2. Bag, M.K, Yadav, M., Mukherjee. A.K. (2016). Bioefficacy of Strobilurin Based Fungicides against Rice Sheath Blight Disease. Transcriptomics, 4, 128. doi:10.4172/23 29-8936.1000128.

3. Beck, C., Koch, H., Oerke, B. C., \& Dehne, H. W. (2000). Einfluss von strobilurinen auf physiologic und ertrag von winterweizen. Mitt. Biol. Bundesanst Land-Forstwirtsch, 376, 479-480.

4. Bingham, I.J., Young, C., Bounds, P., Gravouil, C. \& Paveley, N.D. (2021). Mechanisms by which fungicides increase grain sink capacity and yield of spring barley when visible disease severity is low or absent. Field Crops Research, 261,108011.

5. Debashis, D., Supradip, S., Prasad, R. D. \& B. M. Kumar. (2012). Effect of different active fungicides molecules on the management of rice blast disease. International Journal of Agriculture, Environment and Biotechnol- ogy 5(3): 247-251

6. Dietz, J.I., Schierenbeck, M. \& Simón, M.R. (2019). Impact of foliar diseases and its interaction with nitrogen fertilization and fungicides mixtures on green leaf area dynamics and yield in oat genotypes with different resistance. Crop Protection, 121, 80-88.

7. Fleitas, M.C., Schierenbeck, M., Gerard, G.S., Dietz, J.I., Golik, S.I. \& Simón, M.R. (2018). Breadmaking quality and yield response to the green leaf area duration caused by fluxapyroxad under three nitrogen rates in wheat affected with tan spot. Crop Protection, 106, 201-209.

8. Glynn, C. Percival \& Kelly Noviss1. (2008). Triazole induced drought tolerance in horse chestnut (Aesculus hippocastanum). Tree Physiology, 28, 1685-1692.

9. Gopi, R., Sridharan, R., Somasundaram, R., Lakshmanan, G. M. A. \& Panneerselvam, R. (2005). Growth and photosynthetic characteristics induced by triazoles in Amorphophallus campanulatus Blume. General and Applied Plant Physiology, 31, 171-180.

10. Jiang, X., Wang, Y., Xie, H., Li, R., Wei, J., \& Liu, Y. (2019). Environmental behavior of paclobutrazol in soil and its toxicity on potato and taro plants. Environmental Science and Pollution Research, 26(26), 27385-27395. https ://doi.org/10.1007/s1135 6-019-05947-9.

11. Kamran, M., Wennan, S., Ahmad, I., Xiangping, M., Wenwen, C., et al. (2018). Application of paclobutrazol affect maize grain yield by regulating root morphological and physiological characteristics under a semi-arid region. Scientific Reports, 8(1), 1-15. https :// doi.org/10.1038/ s4159 8-018-23166 -z.

12. Kuai, J., Yang, Y., Sun, Y., Zhou, G., Zuo, Q., Wu, J., et al. (2015). Paclobutrazol increases canola seed yield by enhancing lodging and pod shatter resistance in Brassica napus L. Field Crops Research, 180, 10-20. https :// doi.org/10.1016/j.fcr.2015.05.004.

13. Lima, J. D., Moraes, S., Da Silva, S. \& Da, S. H. M. G. (2012). Physiological responses in the banana plantlets treated with strobilufins. Semina Ciencias Agrarias, 33(1), 77-86.

14. Majumdar, B. A., Saha, R., Sarkar, S., Maji, B. \& Mahapatra, B. S. (2010). Effect of herbicides and fungicides application on fibre yield and nutrient uptake by jute (Corchorus olitorius), residual nutrient status and soil quality. Indian Journal of Agricultural, 80(10), 878-83.

15. McCartney, C., Mercer, P. C., Cooke, L. R. \& Fraaije. B. A. (2007). Effects of a strobilurin-based spray programme on disease control, green leaf area, yield and development of fungicide resistance in Mycosphaerella graminicola in Northern Ireland. Crop Protection, 26(8), 1272-1280.

16. Mehmood, M. Z., Qadir, G., Afzal, O., Din, A. M. U., Raza, M. A., Khan, I., \& Ahmed, M. (2021). Paclobutrazol improves sesame yield by increasing dry matter accumulation and reducing seed shattering under rainfed conditions. International Journal of Plant Production, 1-13.

17. Muhammad ljaz. \& Honermeier, B. (2012). Effect of triazole and Strobilurin fungicides on seed yield formation and grain quality of winter rapeseed (Brassica napus $\mathrm{L}$ ). Field Crops Research, 130, 80-86.

18. Pal, S., Zhao, J., Khan, A., Yadav, N. S., Batushansky, A., Barak, S., Rewald, B., Fait, A., Lazarovitch, N. \& Rachmilevitch, S. (2016). Paclobutrazol induces tolerance in tomato to deficit irrigation through diversified effects on 
plant morphology, physiology and metabolism. Scientific Reports, 6, 39321. https ://doi. org/10.1038/srep3 9321.

19. Patil, C.S., Landge, S.A., Saindane, Y.S. \& Deore, B.V. (2018). Dissipation pattern of trifloxystrobin 25\%+ tebuconazole 50\% WG (Nativo 75\% WG) on cowpea and soil from Western Maharashtra. International Journal of Chemical Studies, 6(2), 2907-2912.

20. Rezende, W.S., Ferreira Júnior, D.D.C., Bueno, T.V., Agostinho, F.B. \& Brito, C.H.D. (2018). Corn stalk integrity is improved by fungicide combinations containing carboxamide. Ciencia e Agrotecnologia, 42(5), 484-490.

21. Ruske, R. E., Gooding, M. J. \& Jones, S. A. (2003). The effects of triazole and strobilurin fungicide programmes on nitrogen uptake, partitioning, remobilization and grain $\mathrm{N}$ accumulation in winter wheat cultivars. Journal of Agricultural Science, 140, 395-407.

22. Sahoo, S.K., Jyot, G., Battu, R.S. et al. (2012). Dissipation Kinetics of Trifloxystrobin and Tebuconazole on Chili and Soil. Bulletin of Environmental Contamination and Toxicology 88, 368-371. https://doi.org/10.1007/ s00128-011-0464-z.
23. Soumya, P., Kumar, P., \& Pal, M. (2017). Paclobutrazol: a novel plant growth regulator and multi-stress ameliorant. Indian Journal of Plant Physiology, 22(3), 267-278. https ://doi.org/10.1007/s4050 2-017-0316-X.

24. Souza, H.M., Dias, A.R., Theodoro, G.F., Osorio, C.R.W.S. \& Magalhaes, F.F. (2020). Cultivar, plant height and fungicide for integrated control of ramularia spot and increased cotton yield. Journal of Agricultural Studies, 8 (2), 224-236.

25. Sundaram, V. (1979). Handbook of Methods of Tests for Fibres, Yarns and Fabrics. CIRCOT, Mumbai.

26. Swoboda, C. \& Pedersen, P. (2009). Effect of fungicide on soybean growth and yield. Agronomy Journal, 101, 352-356.

27. Tesfahun, W. (2018). A review on: Response of crops to paclobutrazol application. Cogent Food \& Agriculture, 4 (1), 1525169. https :// doi.org/10.1080/23311 932.2018.1 525169.

28. Watson, D. J. (1958). The dependence of crop growth rate on plant dry weight. Annals of Botany, 23, 37-54.

29. Yoshida, S. (1971). Fundamentals of rice crop science. IRRI, Loss Banos, Philippines, 260. 